\title{
Az orvosi recept mint szövegtípus a 16-17. században. 2. rész
}

\section{A szövegtípus kognitív megközelítési lehetősége*}

5.3.2. Instrukciós rész. Az iniciátort követi a receptek fö funkcionális egysége, az instrukciós rész, amely részben tartalmazza a szövegtípus központi beszédaktusát, az instrukciót, az utasítást. Ez leggyakrabban igei formákhoz kötődik. $\mathrm{Az}$ instrukció jellemzően a tárgyas igék egy viszonylag szük szemantikai köréből kerül ki, és prototipikusan E/2. személyü felszólító módú igealakban reprezentálódik (végy, törd össze, kenjed stb.). A különféle eljárások igei reprezentációin kívül az instrukciós rész tartalmazza még a szövegtípusban központi fontosságú hozzávalókat és a hozzájuk kapcsolódó mértékeket, mértékegységeket. Ebben a funkcionális részben találhatók meg továbbá az elkészítés módjához, idejéhez, az alkalmazáshoz és az adagoláshoz kapcsolódó információk is. Ezek közül a szövegtípus fó funkciója köré szerveződő fő beszédaktust, az instrukciót mutatom be részletesen.

A receptek fő funkciója az utasítás, az instrukció arra nézve, hogyan érhetjük el a HASZNOSat. Az instrukció leggyakrabban igei szerkezethez kötődik. A korai receptekben az instrukciók nyelvi reprezentációi nagyfokú variabilitást mutatnak. Ez szorosan összefügg az adott beszédhelyzet tipikus, sematikus megalkotási módjaival, a közösség konvencióval, ezek sztenderdizáltsági fokával, valamint az interakció tényezőivel.

Az elemzésben az instrukciót beszédaktusként, a direktívum egy speciális típusaként kezelem, és ennek a közvetlen és a közvetett megjelenési módjaival is foglalkozom, ami szoros összefüggést mutat a TUDÁs és a CSELEKVÉS megoszlásával. Az orvosi receptbeli instrukciót két funkcionális kognitív megközelítésü beszédaktus-modell segítségével mutatom be (CROFT 1994; PANTHER-THORNBURG 1997, 1998). CROFT az illokúciós aktusok grammatikalizációjából indul ki, párhuzamba hozva a gyakori nyelvtani struktúrákat a fó nyelvi funkciókkal (iconic motivation; CROFT 1994: 461). Három fő mondattípust, és ennek megfelelően három fö beszédaktus különít el: a kijelentőt (declarative), a kérdőt (interrogative) és a felszólítót (imperative). Ezeket párhuzamba hozza a TUDÁS-AKCIÓ-ÉRZELEM hármas dimenziójával, a VÉLELEM-VÁGY-INTENCIÓ pszichológiai modelljével, amely a személyközi interakciónak a leírására alkalmazható. Rámutat továbbá arra is, hogy a beszédaktusok nem alkotnak élesen elkülönülö típusokat, hanem fokozatosan helyezhetők el egy kontinuum mentén. Így létezik egy kontinuum a kijelentések és a felszólítások között, a kijelentések és kérdések között, valamint a kijelentések és a felkiáltások között (1. bővebben CROFT 1994: 470).

A korai receptekben fellelhető instrukciók a kijelentő és a felszólító mód kontinuumában ragadhatók meg, jellemzően a TUDÁShoz és CSELEKVÉShez kötődően.

* A tanulmány első részét 1. Magyar Nyelv 112. 2016: 385-400. DOI: 10.18349/Magyar[-] Nyelv.2016.4.385.

Magyar Nyelv 113. 2017: 27-41. DOI: 10.18349/MagyarNyelv.2017.1.27 
Az instrukciók típusait a prototipikus reprezentációtól indulva (felszólítás) mutatatom be a kijelentő mód felé haladva (vö. 4. ábra). Az instrukciókat alapvetően két orvosi könyv (AM., PC.) és két mindennapi receptgyüjteményből vett példák (OLO., MBM.) alapján szemléltetem. A gyakoriság és az egyes recepttípusok öszszefüggéseire csak érintőlegesen térek ki (erről részletesen 1. KuNA 2012a).

\section{4. ábra}

A 16-17. századi orvosi recept instrukciói

\begin{tabular}{|c|c|c|c|c|}
\hline FELSZÓLÍTó MÓD & $\begin{array}{l}1 \\
1 \\
1\end{array}$ & DEONTIKUS MODALITÁS & $\begin{array}{l}1 \\
1 \\
1\end{array}$ & KIJELENTÖ MÓD \\
\hline $\begin{array}{l}\cdot \mathrm{E} / 2 \\
\cdot \mathrm{E} / 3 \\
\cdot \mathrm{T} / 3 \\
\cdot \mathrm{T} / 1 \\
\cdot \text { passziv } \\
\cdot \text { legyen(ek) }\end{array}$ & $\begin{array}{l}1 \\
1 \\
1 \\
1 \\
1 \\
1 \\
1 \\
1 \\
1 \\
1\end{array}$ & • kell + fönévi igenév & $\begin{array}{c}1 \\
1 \\
1 \\
1 \\
1 \\
1 \\
1 \\
1 \\
1 \\
1 \\
1\end{array}$ & $\begin{array}{l}\text { • igeneves szerkezetek } \\
\text { (határozói igenév, melléknév } \\
\text { + fönévi igenév stb.) } \\
\text { • ha - akkor (E/2.) } \\
\text { • összetevök felsorolása } \\
\text { • egyéb kifejezések } \\
\text { (modális kifejezések, } \\
\text { passzív szerkezetek stb.) }\end{array}$ \\
\hline
\end{tabular}

A felszólítás, azon belül is elsődlegesen a második személyü felszólítás tekinthető az instrukció prototipikus nyelvi kifejtésének. Ez megfigyelhető a vizsgált anyagban is, ahol az instrukció leggyakrabban a felszólítás valamilyen formájában konceptualizálódik, hasonlóan más rokon szövegtípusokhoz. A felszólításra jellemző általánosan, hogy a személyközi viszonyokat (az interperszonalitást) jobban előtérbe helyezi a személytelenebb instrukciós formákhoz képest. A korai receptekben a felszólítások lehetnek E/2., E/3., T/3. és ritkán T/1. személyüek, valamint kötődhetnek passzív szerkezethez vagy a legyen felszólító alakhoz (1. 3. táblázat). Az egyes felszólító alakok vonatkozása eltérő lehet. Az E/2. felszólítás jellemzően a gyógyítóhoz szól, de a beteget is megcélozhatja. Az E/3. felszólítás szinte kivétel nélkül a betegre irányul, és megfigyelhető, hogy gyakrabban keveredik más instrukciós mintákkal. A T/3. és T/1. felszólító alakok jóval ritkábban fordulnak elő, mint az egyes számú alakok. Az előbbi általános gyógyító személyekre vonatkozik, míg az utóbbi a szerzőnek a gyógyításba való bevontságát is jelzi. A felszólítás konceptualizálódhat úgy is, hogy nem horgonyzódik le személyhez. Ezek előfordulási aránya szintén alacsony. A legyen típusú felszólítás a gyógyítás körülményeit hangsúlyozza. A passzív felszólítások pedig jellemzően a tudományosabb igényű munkákban jelennek meg, más mintákkal keveredve. 


\section{3. táblázat}

A felszólító módú reprezentációk a 16-17. századi magyar nyelvü receptekben

\begin{tabular}{|l|l|}
\hline $\begin{array}{c}\text { Felszólító módú } \\
\text { alakok }\end{array}$ & \multicolumn{1}{c|}{ Példák } \\
\hline $\begin{array}{l}\text { E/2. személyü } \\
\text { felszólító alak }\end{array}$ & $\begin{array}{l}\text { fözd öszve, kend meg (OLO. 58); reszelj, törd öszve (PC. 4); egyed, } \\
\text { rágjad (MBM. 33); mosd meg (MBM. 121) }\end{array}$ \\
\hline $\begin{array}{l}\text { E/3. személyü } \\
\text { felszólító alak }\end{array}$ & $\begin{array}{l}\text { rakja, töltsön, kösse (OLO. 1513); igyék (PC. 19); rágja (PC. 23); } \\
\text { vegye, szíjjon fel (MBM. 508) }\end{array}$ \\
\hline $\begin{array}{l}\text { T/1. személyü } \\
\text { felszólító alak }\end{array}$ & úgy enyhítsük a fájdalmat (PC. 95) \\
\hline $\begin{array}{l}\text { T/3. személyü } \\
\text { felszólító alak }\end{array}$ & kenjék (OLO. 1366); égessenek, mossák (PC. 1) \\
\hline legyen & $\begin{array}{l}\text { az étel keveses és hideg természetü legyen (AM. I. 3a); kevés ecet is } \\
\text { legyen közte (AM. I. 4b) }\end{array}$ \\
\hline passzív & $\begin{array}{l}\text { borital távoztassék (AM. I. 6b); az gyógyítás kezdessék az érvágá- } \\
\text { son (AM. I. 7a) }\end{array}$ \\
\hline
\end{tabular}

A felszólító módhoz szorosan kapcsolódik a deontikus modalitás, ami ugyan a kijelentő módú instrukciókhoz tartozik, mégsem az egyéb kijelentő módú instrukciókkal együtt tárgyalom. Ezt az is indokolja, hogy a kell + fónévi igenév az utasításban erősen konvencionalizált megvalósulásnak tekinthető. Az E/2. személyü felszólítás mellett a korai receptek második leggyakoribb instrukciós formájának tekinthető, amelyben néhány példától eltekintve a személy kifejtetlen marad (pl. enyhitéshez kell nyúlnunk; PC. 95). Az igeneves konstrukció a kijelentés és a felszólítás kontinuumában található, és gyakran keveredik egy szövegen belül más instrukciós mintákkal.

„A deontikus beszédháttér szabályokból, konvenciókból és a beszélő elvárásaiból, illetőleg az azokat reprezentáló kijelentésekből áll." (KIEFER 2005: 60.) A deontikus beszédhátteret alkothatják olyan kifejezések, amelyek rendelkezéseket vagy személyek közötti hierarchikus viszonyt reprezentálnak. A korai orvosi recept esetében inkább ez utóbbiról van szó, amelyben a hierarchia alapját a gyógyításhoz kapcsolódó TUDÁs szolgáltatja. A mai magyar receptek esetében kell + fönévi igeneves forma soha nem fordul elő, ezek inkább az orvos-beteg kommunikációra, illetve a gyógyszerek használati utasításaira szorítkoznak. A korai receptekben a kell + főnévi igeneves szerkezetekben az intézkedések szükségszerüsége kerül előtérbe: noha a megnyilatkozó TUDÁSánál fogva felelősséget vállal az információért, a kifejezés, a többi igeneves szerkezethez hasonlóan, személytelen. Így az interperszonális viszonyok háttérbe szorulnak, ahogy ez a példákból is látható: kell megönteni és [kell] reá kötni (OLO. 34); eret kell vágatni (PC. 9); mosni kell (PC. 11, 13); meg kell fözni, kenni kell (MBM. 511).

A receptekben a felszólító módú alakokon és a kell + főnévi igeneves instrukciókon túl számos kijelentő módú, indirekt instrukció található. Ezek előfordulási 
gyakorisága, konvencionalizáltsága változó, és sok esetekben összefüggést mutat az orvosi szöveghagyomány szintjeivel, illetve a recepttípusokkal. Jellemző, hogy a kijelentő módhoz kapcsolódó instrukciók az igékben nominális tulajdonságokat mutatnak fel. Olyan utasításokkal is találkozhatunk, amelyekben az igei rész teljesen hiányzik, vagy egy logikai viszony részeként vesz részt a 'hogyan csináld' funkció kifejtésében (vö. 4. táblázat).

\section{4. táblázat}

Az instrukció kijelentő módhoz kötődő reprezentációi

\begin{tabular}{|l|l|}
\hline \multicolumn{1}{|c|}{$\begin{array}{c}\text { Kijelentő módú } \\
\text { reprezentációk }\end{array}$} & \multicolumn{1}{|c|}{ Példák } \\
\hline $\begin{array}{l}\text {-ván/-vén határozói } \\
\text { igenév }\end{array}$ & $\begin{array}{l}\text { egybe elegyitvén (OLO. 372), megtörvén, kifacsarván (PC. 15) } \\
\text { öszvefacsarván (MBM. 513) }\end{array}$ \\
\hline $\begin{array}{l}\text { jó/hasznos + fönévi } \\
\text { igenév/fönév }\end{array}$ & $\begin{array}{l}\text { jó, ha orrába csöpögteti (OLO. 855); megvágatni igen hasznos } \\
\text { (PC. 8.); álom ellen jó (MBM. 427) }\end{array}$ \\
\hline ha-akkor & ha az veronikának vizét veszed, azt iszod (MBM. 1247) \\
\hline $\begin{array}{l}\text { mértékegységek } \\
\text { listázva + minimális } \\
\text { vagy teljesen hiányzó } \\
\text { igei szerkezet }\end{array}$ & $\begin{array}{l}\text { Sárga víz, francuról való. Mastix lott 1, Minium lott fél, } \\
\text { Tömjén lott fél, Hosszú borsó lott negyed, Sáfrány negyed } \\
\text { rész lott negyed, Égett bor egy meszellyel. (TOK. 28) }\end{array}$ \\
\hline
\end{tabular}

Összegzésként elmondható, hogy a 16-17. receptek instrukciós részét változatos nyelvi reprezentáció jellemzi. Az egyes reprezentációk nem ugyanolyan gyakorisággal, és a szöveghagyomány egyes szintjeihez kötődve különböző arányban jelennek meg, sokszor egymással keveredve. Az instrukció jellemzően igei szerkezethez kötődik, és prototipikusan a felszólítás révén, személyközi interakcióban reprezentálódik. A prototipikus instrukciónak az E/2. személyü felszólítás tekinthetö, amely a kell + fónévi igeneves szerkezettel együtt a legkonvencionalizáltabb és leggyakoribb instrukció a szöveghagyománytól függetlenül (1. KUNA 2012a). Ez nagy valószínüséggel összefüggésbe hozható a pálcás ordináció közvetlen nyelvi közegével, az átvett külföldi mintákkal, valamint a TUDÁs által teremtett hierarchiával. Az instrukciónak azonban számos más, nem prototipikus nyelvi formája is megjelenik a felszólítás és a kijelentés kontinuumában a beszélői jelentés más-más aspektusát kiemelve. Az instrukció nem prototipikus reprezentációihoz nyújthat segítséget a PANTHER-THORNBURG $(1997,1998)$ által kidolgozott forgatókönyvmodell, amely a közvetett beszédaktusok leírására tesz kísérletet. A modell alapgondolata az, hogy a beszédaktusoknak van egy általános sémája, forgatókönyve, amelyben vannak a centrumhoz, magkomponenshez közelebbi (CORE, RESULT), valamint a magkomponenstől távolabb eső, periférikusabb elemek (BEFORE; AFTER). $\mathrm{Az}$ indirekt beszédaktus egészét a kognitív forgatókönyv egy eleme is képes aktiválni (PANTHER-THORNBURG 1997: 211, 1998: 768). Ezek alapján a direktívumok (beleértve az instrukciókat) forgatókönyve a következőképpen néz ki (1. 5. ábra): 


\section{5. ábra}

A direktívumok forgatókönyve (PANTHER-THORNBURG 1997: 208)

\begin{tabular}{|l|ll}
\hline $\begin{array}{l}\text { M - megnyilatkozó } \\
\text { A-akció, cselekvés } \\
\text { B-befogadó }\end{array}$ & 1. ELŐTT/BEFORE: & $\begin{array}{l}\text { B meg tudja tenni A-t. } \\
\text { M azt akarja, hogy B tegye meg A-t }\end{array}$ \\
\hline 2. MAG/CORE: & $\begin{array}{l}\text { M egy többé-kevésbé erös kötelesség alá } \\
\text { vonja B-t, hogy tegye meg A-t } \\
\text { B-nek többé-kevésbé kötelessége megtenni A-t } \\
\text { (muszáj/kellene/ajánlatos) }\end{array}$ \\
\hline EREDMÉNY/RESULT: & B megcsinálja A-t (érdeke) \\
\hline 3. UTÁN/AFTER & B.
\end{tabular}

A felszólító mód ennek értelmében az utasítás magkomponenséhez tartozik. A receptbeli felszólító formák között azonban nagy különbség mutatkozik a prototipikalitásban, az előfordulási gyakoriságban, valamint hogy milyen mértékben emelik ki az interakció interperszonális jellegét. Így a T/3. személyü, a passzív szerkezetü, valamint a legyen-hez kapcsolódó felszólításokban ez a funkció kevésbé kerül elötérbe. A felszólításhoz hasonlóan a deontikus modalitású kell + fönévi igeneves konstrukció is a forgatókönyv központi eleméhez tartozik (EREDMÉNY), azonban az interakció inkább személytelen jellegü.

A forgatókönyv-modell és a recept forgatókönyvének összehangolásával magyarázhatóvá válnak az interakcióban az instrukció kevésbé prototipikus esetei is. Azokban a receptekben, amelyekben a hozzávalók mint nominális felsorolások állnak (vö. TOK. 28; 4. táblázat), a periférián található előzetes komponensek (ELÖTT) révén idéződik fel a teljes forgatókönyv. Ez az instrukciótípus egyrészt azt mutatja, hogy a receptekben a hozzávalók központi szerepet játszanak; másrészt mivel ez a típus kizárólag „mindennapi” receptgyüjteményekben fordul elő, ezért elliptikus szerkesztésre utal. A határozói igenév révén a gyógyítás körülményei kerülnek előtérbe, amelyek szintén az előzetes kondíciókhoz tartoznak. Sajátos az egyéb igeneves és az ezekhez kapcsolható nominális szerkezetek helyzete, amelyben általában a HASZNOS válik hangsúlyossá, így az előzetes feltételek része. Ezek a tanácsszerü kifejezések szemantikailag közel állnak a magkomponenshez (kell - szükséges), és még a beszélő attitüdjére is utalnak az adott eljárással, gyógyírral kapcsolatban. A ha-akkor viszonyban ezzel szemben legtöbbször az kerül előtérbe, hogy milyen következményekkel jár, ha valamit megteszünk, alkalmazunk; illetve ha egy adott probléma fennáll, akkor mit kell az eredményes gyógyulás érdekében tenni (UTÁN). A metonimikus forgatókönyv-modell és a szövegtípus forgatókönyvként való értelmezése magyarázhatóvá teszi az interakcióban az instrukció kevésbé prototipikus eseteit is (ennek szövegmegértésben betöltött szerepére 1. 6. fejezet). Fontos azonban megjegyezni, hogy az egyes instrukciótípusok eltérö konvencionalizáltsági fokot mutatnak; jelentős különbségek adódnak az egyes szöveghagyományokban és recepttípusokban; továbbá az instrukció típusai jellemzően egymással keveredve jelennek meg egy szövegen belül. 
5.3.3. Meggyőzés. A meggyőzés a 16-17. századi orvosi receptek harmadik funkcionális egysége, amelyet itt csak röviden mutatok be (részletesen 1. KunA 2011, 2013, 2015). A receptbeli meggyőzések mint funkcionális egységek prototipikusan az egyes szövegek végén jelennek meg, gyakran bármilyen recepthez hozzáilleszthetők (1. pl. probatum est 'próbált dolog', sanabitur 'meggyógyul', használ). A sok esetben latin szöveghagyományból öröklődött kifejezésekre és azok variabilitására a szakirodalom is felhívja a figyelmet (vö. efficacy phrases, tag phrases, stock phrases; STANNARD 1982; JONES 1998; TAAVITSAINEN 2001b; KESZLER 2012). A meggyőzések ezen szövegvégi kifejezései egyrészt a latin minta követésére utalnak, másrészt a pozitív attitüd kialakítását szolgálják, harmadrészt pedig szövegszervező funkciójuk van. A receptbeli meggyőzésnek a prototípusáról elmondható tehát, hogy az egyes szövegek lezárásaként, annak végén jelenik meg. Jellemzően általános hatókörü, azaz a receptek szinte minden típusához hozzáilleszthetö. Sokszor kiegészül más információkkal, ugyanakkor önmagában is előfordulhat.

A meggyőző funkció, a pozitív attitüd kialakítása azonban nemcsak ezekhez a szöveg végén megjelenő, szinte ,automatikusan” használható kifejezésekhez kötődhet. A meggyőzés lényegében tekinthető egy szövegalkotói stratégiának, amelyben az értéktulajdonítás, különösen a pozitív pólus kifejtése, központi szerepet kap (KUNA 2015). Ennek fogalmi kidolgozásában szerepet kaphatnak a recept forgatókönyvének, szorosabban véve a GYÓGYULÁS sémájának különböző elemei. Igy előtérbe kerülhet a testi-lelki egyensúly; a betegség kialakulása, oka; a betegség müködése, elmúlása; a gyógyításra vonatkozó tudás és tapasztalat, az abban részt vevő személyek; a terápia, a gyógyító eljárások és szerek. A recept sémájához kötődően a meggyőző funkció kidolgozása alapvetően metonimikusan történik. A pozitív értéktulajdonítást bizonyos forgatókönyvbeli tényezők aktiválódása vagy együttes aktiválása hozza létre. Ezeket a fogalmi kategóriákat foglalja össze az 5. táblázat, amely a 8 pszichológus hallgatóval végzett validálás és a több mint 10000 recept elemzésének az eredménye. A példákból is látni fogjuk, hogy az egyes kategóriák gyakran együtt, egymást erősítve jelennek meg; ezek részleteire itt azonban nem térek ki (erről 1. bővebben KUNA 2015).

\section{5. táblázat}

A meggyőzés fogalmi kategóriái a 16-17. századi receptekben

\begin{tabular}{|c|c|c|}
\hline $\begin{array}{l}\text { A kód } \\
\text { száma }\end{array}$ & A fogalmi kategória & Példa \\
\hline 1. & $\begin{array}{l}\text { ÁLTALÁNOS POZITÍV } \\
\text { ÉRTÉK }\end{array}$ & \\
\hline 1.1 . & $\begin{array}{l}\text { JÓSÁG/SZÉPSÉG/ } \\
\text { KELLEMESSÉG }\end{array}$ & $\begin{array}{l}\text { Táskás sebnek ez igen jó orvosság (AM. IV.12b); és } \\
\text { nagy fájdalmakat elveszen róla, és nagy gyönyörü- } \\
\text { séggel altatja. (OLO. 1) }\end{array}$ \\
\hline 1.2 . & HASZNOSSÁG & $\begin{array}{l}\text { igen jó és hasznos (AM. I. 212a); italban betegnek } \\
\text { add innia és használ (HP. 62) }\end{array}$ \\
\hline 1.3 . & $\begin{array}{l}\text { CSODA/ } \\
\text { CSODÁLATOSSÁG }\end{array}$ & $\begin{array}{l}\text { Ez csodálatosképpen használ (AM. I. 211a); csoda } \\
\text { hasznos dolog (AM. V. 5b) }\end{array}$ \\
\hline
\end{tabular}




\begin{tabular}{|c|c|c|}
\hline 1.4. & $\begin{array}{l}\text { OKOSSÁG/ } \\
\text { BÖLCSESSÉG }\end{array}$ & $\begin{array}{l}\text { bölcs Arisztotelész így írja (AM. I. 277b); ezt mond- } \\
\text { ják az bölcs fizikusok (AM. I. 277b) }\end{array}$ \\
\hline 1.5 . & $\begin{array}{l}\text { FONTOSSÁG/ } \\
\text { HÍRESSÉG }\end{array}$ & $\begin{array}{l}\text { Ez orvosság Galénusz fö és igön titkos orvossága } \\
\text { volt. (AM. I.75b) }\end{array}$ \\
\hline 1.6. & SZERENCSE & Így jó szerencséd lészen (HP. 213) \\
\hline 1.7. & $\begin{array}{l}\text { egyéb, } \\
\text { pl. KÖNNYÜSÉG, ERÖ }\end{array}$ & $\begin{array}{l}\text { minden eröltetés nélkül kitisztítja az rossz nedves- } \\
\text { séget (MBM. 508) }\end{array}$ \\
\hline 2. & FOKOZOTTSÁG & $\begin{array}{l}\text { soha oly erős fájdalom nem lehet, kit harmad na- } \\
\text { pig meg nem gyógyít (HP. 138); minden mérget kiüz } \\
\text { emberből (MBM. 1247) }\end{array}$ \\
\hline 3. & KIPRÓBÁLTSÁG & $\begin{array}{l}\text { igen megpróbáltatott orvosság ez (AM. V. 12b); } \\
\text { probatum est (TOK. 1) }\end{array}$ \\
\hline 4. & BIZONYOSSÁG & \\
\hline $\begin{array}{l}4.1 . \\
4.2 .\end{array}$ & $\begin{array}{l}\text { BIZONYOS/ } \\
\text { KÉTSÉGES }\end{array}$ & $\begin{array}{l}\text { Bizonyos és próbált orvosság ez. (AM. I. 312b); Ál- } \\
\text { mot hoz kétség nélkül. (AM. I. 15b) }\end{array}$ \\
\hline 5. & IDÖTÉNYEZÖ & \\
\hline $\begin{array}{l}5.1 . \\
5.2 .\end{array}$ & $\begin{array}{l}\text { HAMARSÁG }([+/-]) / \\
\text { MEGKÉSETTSÉG }\end{array}$ & $\begin{array}{l}\text { a fogad fájása hamar elmúlik (AM. I. 83a); azonnal } \\
\text { megszünik a fájdalom (AM. I.3a); soha jobb annál } \\
\text { nincsen (AM. IV.7b) }\end{array}$ \\
\hline 6. & $\begin{array}{l}\text { A TERÁPIA } \\
\text { EREDMÉNYE }\end{array}$ & \\
\hline 6.1 . & GYÓGYULÁS & \\
\hline 6.1 .1 & MEGGYÓGYULÁS & $\begin{array}{l}\text { három éjjel meggyógyítja (AM. II. 19b); Ez meg- } \\
\text { gyógyítja szépen. (MBM. 135) }\end{array}$ \\
\hline 6.1 .2 & $\begin{array}{l}\text { A BETEGSÉG VÉGE } \\
\text { (TÁVOZÁSA, } \\
\text { MEGSZÜNÉSE, } \\
\text { ELPUSZTÍTÁSA) } \\
\end{array}$ & $\begin{array}{l}\text { megszünik a fogfájás (MOR. 214); a kórság elhagy- } \\
\text { ja (TOK. 111); vízi betegséget elüzi és mindeféle } \\
\text { hideglelést (MBM. 125); állitja az fenét (MBM. } \\
\text { 1299); megáll az, az mérgét kivonsza (MOR. 170) }\end{array}$ \\
\hline 6.1 .3 & $\begin{array}{l}\text { ÁLLAPOTVÁLTOZÁS } \\
\text { (TISZTÍTÁS/ } \\
\text { MEGERÖSÍTÉS) }\end{array}$ & $\begin{array}{l}\text { az szívet megerösíti (AM. I. 124a); kitisztítja a huru- } \\
\text { tot (HP. 26); megépíti gyomrát (HP. 34); igen enyhül } \\
\text { véle (MBM. 28) }\end{array}$ \\
\hline 6.2 . & HALÁLOSSÁG & $\begin{array}{l}\text { kétségtelenül az olyan meghal (AM. I. 109b); meg- } \\
\text { hal, nem él meg (MBM. 36) }\end{array}$ \\
\hline 7. & HITELESSÉG & \\
\hline 7.1. & $\begin{array}{l}\text { A RECEPT SZERZÖJE } \\
(\mathrm{E} / 1 .)\end{array}$ & $\begin{array}{l}\text { Ez orvosságot én Lencsés György megpróbáltam, és } \\
\text { igen igaznak találtatott. (AM. I. 77b); Magam pró- } \\
\text { báltam dolog. (KP. 5) }\end{array}$ \\
\hline 7.2 . & $\begin{array}{l}\text { HARMADIK SZEMÉLY } \\
(\mathrm{E} / 3 . \text { VAGY T/3.) }\end{array}$ & \\
\hline 7.2.1. & $\begin{array}{l}\text { KONKRÉT (ÁLTALÁBAN } \\
\text { NEVES) SZEMÉLY }\end{array}$ & $\begin{array}{l}\text { Adorján doktor orvossága. (AM. I. 96b); Plinus mond- } \\
\text { ja'(MBM. 393); Galenus azt mondja (OLO. 580) }\end{array}$ \\
\hline 7.2 .2 & $\begin{array}{l}\text { ÁLTALÁNOS (NEM } \\
\text { KONKRÉT) SZEMÉLY }\end{array}$ & $\begin{array}{l}\text { És azt mondják az bölcs fizikusok (AM. I. 277b); } \\
\text { Ezt egy vénasszony próbálta (AM. I. 295b) }\end{array}$ \\
\hline
\end{tabular}




\begin{tabular}{|c|c|c|}
\hline 7.2 .3$. & $\begin{array}{l}\text { ISTENRE VALÓ } \\
\text { HIVATKOZÁS }\end{array}$ & $\begin{array}{l}\text { Istennek akaratjábúl bizonnyal használ (OLO. 1252); } \\
\text { Isten akaratjából megnehézkesedik [teherbe esik] } \\
\text { (AM. I. 270b) }\end{array}$ \\
\hline 8. & $\begin{array}{l}\text { ÉRZELMI } \\
\text { BEVONTSÁG }\end{array}$ & \\
\hline 8.1 . & $\begin{array}{l}\text { POZITÍV ÉRZELMI } \\
\text { BEVONTSÁG }\end{array}$ & $\begin{array}{l}\text { Ezt elhidd bár (MBM. 16); Köszvényes barátom, } \\
\text { próbáld meg, nem hagysz hazugságban, ebben is, } \\
\text { hidd el bár. (MBM. 840) }\end{array}$ \\
\hline 8.2 . & $\begin{array}{l}\text { NEGATÍV ÉRZELMI } \\
\text { BEVONTSÁG }\end{array}$ & $\begin{array}{l}\text { hogy be ne igyék benne, mert megárt néki (MBM. } \\
1137)\end{array}$ \\
\hline 9. & $\begin{array}{l}\text { INDOKLÁS } \\
\text { (ÉRVELÉS) }\end{array}$ & mert azt mondja Auissenna, hogy (TOK. 352) \\
\hline 10. & $\begin{array}{l}\text { egyéb: A GYÓGYÍTÁS } \\
\text { HELYE; IMÁDKOZÁS, } \\
\text { MÁGIKUS ELJÁRÁS }\end{array}$ & $\begin{array}{l}\text { Jeruzsálemi fö orvosság. (KP. 3); és jól lösz: } \\
X 9 X X 5 X O C X 3 X \text { (HP. 208); mond el az Páter nostert } \\
\text { és Ave Mariát. (KP. 27) }\end{array}$ \\
\hline
\end{tabular}

6. Szövegmegértés és szövegtípus-aktiválás a 16-17. századi orvosi receptekhez kötődően. Az egyes funkcionális egységek kapcsán érdemes megvizsgálni, hogy ezek milyen szerepet töltenek be a szövegmegértésben és a szövegtípus-aktiválásban. Másként fogalmazva, kereshetjük arra a választ, hogy a korai receptek forgatókönyvének mely elemei képesek a legkönnyebben felidézni a szövegtípust és annak sémáját; továbbá hogy milyen szempontok irányítják a mindennapi beszélők szövegtípus-osztályozását. Az alábbi kérdés irányította az 1500 adatközlővel készített empirikus felmérést, amelynek alapját a történeti szöveg adta, és mai magyar beszélők körében készült. Az empirikus felmérésben három korcsoport vett részt: középiskolások (14-19 év), egyetemi, föiskolai hallgatók (18-25 év), illetve 35-45 év közötti felnőttek. A felmérés 25 különböző szövegegységhez kapcsolódóan vizsgálja a szövegtípus-tudást irányító tényezőket. Mind a 25 kérdő́ivet 20 adatközlő töltötte ki minden korcsoporton belül. Ez korcsoportonként 500 adatközlöt jelent, azaz összesen 1500 -at. A 25 vizsgált szövegegység tartalmaz iniciátorokat (8 reprezentációt); mértékegységeket (2); adagolásra vonatkozó információkat (1); instrukciós reprezentációkat (8); meggyőző funkciójú szövegrészeket (6). A kérdőív minden esetben rákérdezett az alábbi információkra: „Milyen típusú szövegből származhat a kifejezés?”; „Miért gondolja ezt?”; „Hol olvashatja/ hallhatja?”; „Milyen korhoz kötődik?”. Jelen tanulmány a középiskolások és a felsőoktatásban részt vevők válaszaiból levonható következtetéseket mutatja be, és az eredményeket nem teljességükben, csak néhány aspektust kiemelve szemlélteti.

Az empirikus felmérés hipotézisalkotásában, illetve tervezésében figyelembe kellett venni, hogy a vizsgálat az egyes korok társadalmi-kulturális változásai miatt hordoz némi ellentmondást, ugyanis a mai magyar beszélők szövegtípus-felismerési és -megértési stratégiáit vizsgálja a korai receptek kapcsán. A vizsgálat mégis indokolt, hiszen egyrészt a szövegek történeti jellege miatt a korabeli szövegtípustulajdonítás nem vizsgálható, másrészt a recept mint szövegtípus és mint funkció fennmaradása és folyamatossága lehetővé teszi a korokon túlnyúló értelmezést. 
Ez szükségszerüen a 21. századi beszélő perspektívájából történik, ezért bizonyos szempontból korlátozott. Ezeket a tényezőket figyelembe vettem a hipotézisek felállításakor, illetve az eredmények értelmezésekor egyaránt.

Kiindulási hipotéziseim ennek megfelelően a szövegtípus-felismerésre vonatkozóan a következők voltak. 1. Feltételeztem, hogy a középiskolás korosztály szövegtípus-meghatározásait és azok megnevezéseit nagyban az adott kifejezések témája irányítja; fontos szerepet kap továbbá az iskolában tanult szövegtípus-ismeretek bevonása. Ezzel szemben az egyetemisták esetében a szövegtípusokkal szerzett tapasztalatok nagyobb teret kapnak. 2. Feltételeztem továbbá, hogy az egyes szövegegységek közül az E/2. sz. felszólító módú és a kell + főnévi igeneves instrukció fogja felidézni leginkább a recept forgatókönyvét. A meggyőzések pedig a legkevésbé. A továbbiakban 5 szövegegységre vonatkozóan ismertetem az eredményeket.

\section{6. táblázat}

Szövegtípus-tulajdonítások a korai receptek szövegegységeihez kapcsolódóan

\begin{tabular}{|c|c|c|}
\hline Szövegegység & $\begin{array}{c}\text { Középiskolások } \\
\text { szövegtípus-meghatározásai }\end{array}$ & $\begin{array}{c}\text { Egyetemisták } \\
\text { szövegtípus-meghatározásai }\end{array}$ \\
\hline hasfájás & $\begin{array}{l}\text { dokumentum, orvosi, } \\
\text { tudományos }\end{array}$ & $\begin{array}{l}\text { ismeretterjesztő, orvosi szakszö- } \\
\text { veg, alternatív gyógyászat, csecse- } \\
\text { mőkről szóló könyv, publicisztika, } \\
\text { köznyelvi szöveg, női magazin }\end{array}$ \\
\hline okádás ellen & $\begin{array}{l}\text { hétköznapi, orvosi, } \\
\text { szakszöveg }\end{array}$ & $\begin{array}{l}\text { hétköznapi tanácsadás, betegtá- } \\
\text { jékoztató, blog, köznyelvi, poszt- } \\
\text { modern novella }\end{array}$ \\
\hline $\begin{array}{l}\text { alopaticum, timsó, tik- } \\
\text { mony fehérje, bonus } \\
\text { aarmenus, mastix }\end{array}$ & $\begin{array}{l}\text { tudományos, szakszöveg, } \\
\text { ismeretterjesztő }\end{array}$ & $\begin{array}{l}\text { tudományos, szakszöveg, isme- } \\
\text { retterjesztő, orvosi, biológia }\end{array}$ \\
\hline uncia, pint, icce & $\begin{array}{l}\text { régies, szakszöveg, közéleti, } \\
\text { hivatalos, idegenből fordított, } \\
\text { elavult, mértékegység }\end{array}$ & $\begin{array}{l}\text { mértékegységek, néprajzi, bo- } \\
\text { rászati szakszöveg, tudományos } \\
\text { kifejezések, fordítás, régies, né- } \\
\text { pies, tudományos, szakszöveg }\end{array}$ \\
\hline $\begin{array}{l}\text { végy, mess ketté, törd } \\
\text { össze, tégy }\end{array}$ & $\begin{array}{l}\text { felszólító, régi nóta, mese, } \\
\text { vers, instrukció, recept }\end{array}$ & $\begin{array}{l}\text { recept, bibliai szöveg, fözéssel } \\
\text { kapcsolatos, archaikus, felszólító }\end{array}$ \\
\hline $\begin{array}{l}\text { kell venni, kell } \\
\text { ketté metszeni, kell } \\
\text { összetörni, kell tenni }\end{array}$ & $\begin{array}{l}\text { érvelö, felszólító/ } \\
\text { kényszerítö/utasító szöveg, } \\
\text { recept, kertészeti }\end{array}$ & $\begin{array}{l}\text { bevásárlólista, útmutató, leírás, } \\
\text { hétköznapi tájékoztató, szakács- } \\
\text { könyv, recept, használati utasítás, } \\
\text { utasító, szakszöveg, mezőgazda- } \\
\text { sági, formális }\end{array}$ \\
\hline $\begin{array}{l}\text { bizonyos, kétség } \\
\text { nélkül hat, ezt } \\
\text { bizonnyal tudom, } \\
\text { hogy próbált }\end{array}$ & $\begin{array}{l}\text { érvelő, hivatalos, regény, érte- } \\
\text { kezés, újságban szereplö, hir- } \\
\text { detés, reklám }\end{array}$ & $\begin{array}{l}\text { meggyőző, rábeszélő, reklám, hir- } \\
\text { detés, blog, érvelő }\end{array}$ \\
\hline
\end{tabular}


Az adatközlők válaszaiból azt láthatjuk, hogy a mai magyar beszélők számára a kiválasztott szövegegységek közül az E/2. felszólítás és a kell + fönévi igenév képes önmagában is felidézni a receptet mint szövegtípust. A felszólító reprezentációk az egyetemisták 60\%-ánál hívta elő a receptet, míg a kell + főnévi igenév csak 20\%-ban. Ez az arány a középiskolások esetében $25 \%$ a felszólításnál, és $10 \%$ a kell + fönévi igenévnél. Az utóbbi csoportnál azonban nagyobb arányú az utasítás/instruktív/felszólító/kényszerítő meghatározás feltünő módon a deontikus modalitáshoz kapcsolódóan (75\%). A többi szövegegység meghatározásainál semmilyen mértékben nem hívódik elő a recept forgatókönyve. Az első hipotézis így igazolódott az igei instrukciókra vonatkozóan, azonban nemcsak a meggyőzés, hanem a többi szövegegység sem hívja elő a recept sémáját a felmérés alapján. Az eredmények arra is felhívják a figyelmet, hogy a történeti szövegek szociokulturális háttere jelentősen eltér a maitól. Ezzel a szövegtípus társas-kulturális meghatározottsága is előtérbe kerül.

A nagyobb mintából kiválasztott néhány példa rámutat a szövegtípusok mindennapi kategorizációjának számos jellemzőjére és aspektusára is. Így például látható, hogy a kategorizáció korántsem egy szempont szerint történik. Az egyes szövegegységek által felidézett témán túl a diskurzustartományok (orvosi, biológiai); a használati rétegek (köznyelvi, szaknyelvi, tudományos, irodalmi), a szöveg lehetséges keletkezésének kora (modern, régies, archaikus); a szöveg idegen forrása (fordított szöveg); a tanult ismeretek (posztmodern próza, vers); valamint a szövegtípusokkal szerzett tapasztalatok is szerepet kapnak. A sokszínüség részben összefügg azzal, hogy a kontextus nélküli szövegegységek elhelyezése, tipologizálása más szövegmegértési, szövegaktiválási stratégiát kíván meg, mint egy teljes szöveg kategorizációja. Ugyanakkor megfigyelhető, hogy a mindennapi kategorizáció korántsem egységes elvek alapján történik. Látható továbbá, hogy az adatközlők kora is szerepet kap a tipologizálás szempontjaiban. A középiskolások meghatározásai és kategóriái egységesebb képet mutatnak, valamint az iskolában szerzett ismereteik is nagyobb mértékben érvényesülnek (regény, vers, érvelö szöveg stb.). Az egyetemisták esetében megfigyelhetö, hogy a tanult ismereteken túl a szövegtípusokkal való személyes tapasztalat is nagyobb teret kap. Erre utal a szélesebb körü, részletesebb kategorizáció (csecsemőkről szóló könyv, női magazin stb.)

7. Összegzés. Jelen tanulmány a magyar nyelvü 16-17. századi orvosi receptet mint szövegtípust mutatta be kognitív nyelvészeti keretben. ${ }^{1}$ A receptek elemzésében központi szerepet kapott a szövegtípus emberi megismerésben és a társas-kulturális kontextusban betöltött szerepe. A tanulmány a szövegtípust forgatókönyvként, azaz komplex sémaként, tudásként értelmezte, amely egyszerre közösségi és egyéni tudás. Ebben a komplex sémában a formai-grammatikai jegyek mellett (és azok értelmezésében is) fontos szerepet kap a szövegtípusok kommunikatív-társadalmi meghatározottsága, szociokulturális háttere. Láthattuk,

${ }^{1}$ Helyesbítés: a recept, recep és a recipe megnevezések a mindennapi receptgyüjteményekben a 16. századtól viszonylag gyakran jelennek meg. A tanulmány első részében említett 14. századi megjelenésük téves közlés. 
hogy a 16-17. században a recept a mai használatnál (orvosi és konyhai) sokkal szélesebb körü funkcióval bírt, és alapszintü szövegtípusként müködött. Az egyes altípusokat a 'hogyan csináld' funkció fogta össze. Az egyes altípusok jellemzően tematikusan szerveződtek, eltérő mértékben konvencionalizálódtak, és váltak esetleg önálló szövegtípussá (konyhai recept, betegtájékoztató stb.). Összekapcsolódásuk és szétválásuk a társas-kommunikatív igényekkel szoros összhangban történt és történik, így a szövegtípusok dinamikus és hálózati jellegére is felhívja a figyelmet.

A szövegtipológiai vizsgálat során kiemelkedő szerepet kaptak a prototipikusan megjelenő információk és azok funkcionális szerveződése. A korai receptekben jellemzően három ilyen egység figyelhető meg. 1. Az iniciátor, amely megnyitja egy betegség vagy gyógyszer fogalmi tartományát, és ezzel bevezeti a további információkat. 2. A második egység az instrukciós rész, amely tartalmazza a recept fő funkcióját kifejtő instrukciót, továbbá a mértékegységeket és az adagolásra vonatkozó információkat. 3. A harmadik egység a meggyőzés, amely az eljárás vagy a gyógyszer hatásosságát helyezi előtérbe. A három funkcionális egység prototipikusan megjelenik az egyes szövegekben, de nem tekinthetők kötelezőnek. Megfigyelhettük továbbá, hogy a mai receptekkel ellentétben ezek a részek nagyon változatos nyelvi formában jelentek meg, összefüggést mutatva a korabeli szöveghagyomány egyes szintjeivel és a receptek típusaival.

Mind a korabeli szövegek felépítése, mind a mai magyar beszélők körében végzett vizsgálat arra utal, hogy a recept egyik fó jellemzője az instrukció, ami akár önmagában is képes előhívni a szövegtípus egészének a forgatókönyvét. A leggyakoribb és a legkonvencionalizáltabb reprezentációk az E/2. sz. felszólítások és a kell + főnévi igenév szerkezetek voltak a 16-17. században. A mai beszélők körében is ez hívja elő leginkább a recept szövegtípusát. Habár az empirikus felmérés több szempontból is csak korlátozottan alkalmas a szövegtípusnak mint sémaaktivációnak (ebben az esetben forgatókönyv-aktivációnak) a bemutatására, mégis több tanulsággal szolgál. 1. Rámutat, hogy a szövegtípus egyéni és társas tudás, amely egy adott kommunikatív helyzetben aktiválódik. Tehát kognitívan és diszkurzívan meghatározott. 2. Azt is láthatjuk, hogy a mindennapi szövegtípus-kategorizáció nem egyetlen egységes szempontrendszer szerint történik. A szövegtípus-felismerés összefüggésben van a mindennapi tapasztalatokkal, a tanultság fokával, valamint a szöveg és a szövegbefogadás szociokulturális környezetével is. Ennek megfelelően dinamikusan müködik. 3. Az elemzés felveti továbbá a szövegtípus fó kommunikatív funkciójával összhangban, a beszédaktusok és szövegtípusok kapcsolatának vizsgálatát, valamint annak a szövegtípus-felismerésben betöltött szerepét.

A hosszú történelmi múlttal és fontos társadalmi relevanciával rendelkező szövegtípusok, mint többek között a receptek, alkalmas kutatási keretül szolgálnak a szövegtípusok alakulástörténetének megragadására, és számos szövegmegértéshez és -feldolgozáshoz kötődő empirikus kutatás alapjául is szolgálhatnak.

Kulcsszók: orvosi recept, szövegtípus, forgatókönyv, kognitív nyelvészet, iniciátor, instrukció, meggyőzés. 


\section{Források}

AM. = Ars Medica Electronica: Váradi Lencsés György (1530-1593). Kiadta SzABó T. ATTILA - Bíró Zsolt. CD-ROM. BioTár Electronic, Gramma 3.1. \& 3.2. MTA EME - BDF - VE, Budapest-Kolozsvár-Szombathely-Veszprém, 2000.

HofFMANN GIZELLA szerk. 1989. Medicusi és borbélyi mesterség. Régi magyar ember-és állatorvosló könyvek. Radvánszky Béla gyüjtéséből. JATE, Szeged.

HP. = Házi patika. [1663 k.]. In: HofFMANN szerk. 1989: 227-246.

KP. = Váradi Vásárhelyi István: Kis patika. [1628.] In: HoFFMANN szerk. 1989: 211-225. MBM. = Váradi Szabó György: Medicusi és borbélyi mesterség. [1668-1703.] In: HofFMANN szerk. 1989: 341-434.

MOR. = Mindenféle orvosságoknak rendszedésse. [17. sz. 2. fele.] In: HoFFMANN szerk. 1989: 459-472.

OLO. = Török János: Orvoskönyv. Lovak orvoslása. [1619 k.] In: HoFFMANN szerk. 1989: 377-171.

PC. = Pápai Páriz Ferenc: Pax Corporis. [1695.] In: SZABLYÁR FERENC szerk., Pápai Páriz Ferenc: Pax Corporis. Magvető Könyvkiadó, Budapest, 1984.

TOK. = Szentgyörgyi János: Testi orvosságok könyve. [1619 k.] In: HofFMANN szerk. 1989: 173-201.

\section{Hivatkozott irodalom}

AlOnSO-AlmEIDA, FRANCISCO 2008. The Middle English charm: register, genre and text types variables. Neuphilologische Mitteilungen 109: 9-38.

BAHTYIN, MiHAIL 1988. A beszéd müfajai. In: KANYÓ ZOLTÁN - SíKLAKI IsTVÁN szerk., Tanulmányok az irodalomtudomány köréböl. Tankönyvkiadó, Budapest. 246-280.

BENKE JÓZSEF 2007. Az orvostudomány története. Medicina Könyvkiadó, Budapest.

BÓKAY ÁRPÁD 1897. Vénygyüjtemény. A magyar gyógyszerkönyv második kiadása és pótfüzete alapján. Ötödik javitott és tetemesen bövitett kiadás. Singer és Wolfner, Budapest.

BRDAR-SZABÓ RITA - BRDAR, MARIO 2009. Indirect directives in recipes: a cross-linguistic perspective. Lodz Papers in Pragmatics 5/1. Special Issue on Speech Actions. 107-131. http://dx.doi.org/10.2478/v10016-009-0006-x

CARrol, RUTH 1999. The Middle English recipe as a text-type. Neuphilologische Mitteilungen 100: 27-42.

CARROL, RUTH 2004. Middle English recipes: Vernacularisation of a text-type. In: TAAVITSAINEN, IRMA - PAHTA, PÄIVI eds., Medical and scientific writing in late medieval English. Cambridge University Press, Cambridge. 174-195.

CROFT, WILLIAM 1994. Speech act classification, language typology and cognition. In: Tsohatsidis, SaVAs L. ed., Foundation of speech act theory. Philosophical and linguistic perspectives. Routledge, London. 460-477.

EysencK, Michael W. - KeAne, MARK T. 2003. Kognitív pszichológia. Budapest: Nemzeti Tankönyvkiadó.

ÉKsz. ${ }^{2}$ = Magyar értelmező kéziszótár. Főszerk. PUSZTAI FERENC. 2., átdolgozott kiadás. Akadémiai Kiadó, Budapest, 2003.

Fillmore, ChARles 1977. Scenes-and-frames semantics. In: ZAMPOLLI, ANTONIO ed., Linguistics structures processing. North Holland Publishing Company, Amsterdam New York. 55-81. 
GÖRLACH, MANFRED 1992. Text-types and language history: the cookery recipe. In: RISSANEN, MATTI - IHALAINEN, OSSI - NEVALAINEN, TERTTU - TAAVITSAINEN, IRMA eds., History of Englishes. New Methods and interpretations in historical linguistics. Mouton de Gruyter, Berlin-New York. 736-761. http://dx.doi.org/10.1515/9783110197167.121

GÖRLACH, MANFRED 2004. Text types and the history of English. Mouton de Gruyter, Berlin - New York. http://dx.doi.org/10.1515/9783110197167

GRABARITS ISTVÁN 2009. A gyógyszerkönyvek születése. In: BőSZE PÉTER szerk., A magyar orvosi nyelv tankönyve. Medicina Könyvkiadó, Budapest. 119-146.

GRUND, PETER 2003. The golden formulas: Genre conventions of alchemical recipes in the Middle English period. Neuphilologische Mitteilungen 104: 455-475.

HeINEMANN, WolfGAng 2000a. Textsorte - Textmuster - Texttyp. In: BRINKER, KLAUS Antos, GERD - HeINEMANn, WolfGANG - SAGER, SVEN FrEDERIK eds., Text- und Gesprächslinguistik. Ein internationales Handbuch zeitgenössischer Forschung. I Linguistics of Text and Conversation. An International Handbook of Contemporary Research. Handbücher zur Sprach- und Kommunikationswissenschaft 16.1. Walter de Gruyter, Berlin - New York. 507-523.

HeInEMAnN, WolfGang 2000b. Aspekte der Textsortendifferenzierung. In: BRINKER, Klaus - Antos, Gerd - Heinemann, WolfGANG - SAGER, SVEn FrEDERIK eds., Text- und Gesprächslinguistik. Ein internationales Handbuch zeitgenössischer Forschung. Linguistics of Text and Conversation. An International Handbook of Contemporary Research. Handbücher zur Sprach- und Kommunikationswissenschaft 16.1. Walter de Gruyter, Berlin - New York. 523-546.

HoppÁl MiHÁly 1990. Népi gyógyítás. In: Hoppál MiHÁly szerk., Magyar néprajz 7. Akadémiai Kiadó, Budapest. 693-724.

Hunt, TONY 1990. Popular Medicine in thirteenth-century England: Introduction and texts. D.S. Brewer, Cambridge.

KIEFER, FERENC 2005. Lehetőség és szükségszerüség. Tinta Kiadó. Budapest.

KOCSÁNY PIROSKA 1989. Szövegnyelvészet vagy szövegtípusok nyelvészete? Filológiai Közlöny 35/1: 26-43.

KOCSÁNY PIROSKA 2006. A szövegtipológia eredményei és/vagy eredménytelenségei. In: TolcSVAI NAGY GÁBOR szerk., Szöveg és szövegtípus. Szövegtipológiai tanulmányok. Tinta Könyvkiadó, Budapest. 17-26.

KUNA ÁGNES 2009. Az orvosi vény alakulása a kezdetektől napjainkig. In: BALÁzS GÉZA H. VArga GyUla szerk., Semiotica Agriensis 6. Magyar Szemiotikai Társaság - Líceum Kiadó, Budapest-Eger. 401-410.

KUNA ÁGNES 2011. A 16-17. századi magyar nyelvü orvosi recept szövegtipológiai és pragmatikai vizsgálata funkcionális-kognitiv keretben. Doktori disszertáció. ELTE, Budapest.

KUNA ÁGNES 2012a. Stílusmintázatok a 16-17. századi orvosi receptekben. Történeti stilisztikai elemzés kognitív nyelvészeti keretben. In: TÁTRAI SzILÁRD - TOLCSVAI NAGY GÁBOR szerk., A stílus szociokulturális tényezői. Kognitív stilisztikai tanulmányok. ELTE, Budapest. 303-345.

KUNA ÁGNES 2012b. Az orvosi receptek alakulása a társadalmi és kulturális tényezők függvényében a 16. századtól napjainkig. In: BALÁZs GÉZA - VESZELSZKI ÁGNES szerk., Nyelvés kultúra. Kulturális nyelvészet. Magyar szemiotikai tanulmányok 2526. Inter Kultúra-, Nyelv- és Médiakutató Központ Kht. - Magyar Szemiotikai Társaság - PRAE.HU Kft. - Palimpszeszt Kulturális Alapítvány, Budapest. 156-162. 
KunA ÁGNES 2014. Meggyőzési stratégiák az Ars Medicában (1577 k.). In: ForGÁCS TAMÁS - NÉMETH MIKLÓS - SINKOVICS BALÁZS (szerk.): A nyelvtörténeti kutatások újabb eredményei VII. SZTE Magyar Nyelvészeti Tanszék, Szeged. 105-124.

KUNA ÁGNES 2015. A meggyőzés nyelvi mintázatai a 16-17. századi orvosi receptben. Kognitiv nyelvészeti elemzés. Doktori disszertáció. ELTE, Budapest. http://dx.doi.[-] org/10.15476/ELTE.2015.205

KUNA, ÁGNES 2016a. Genre in a cognitive functional framework. Medical recipe as a genre in 16th and 17th century Hungarian. In: STUKKER, Ninke - SPOOREN, WiLBERT SteEn, Gerard eds., Genre in Language, Discourse and Cognition. De Gruyter, Berlin - New York. 193-224.http://dx.doi.org/10.1515/9783110469639-009

KunA ÁGNes 2016b. A Magyar Orvosi Nyelv Korpusza. Magyar Orvosi Nyelv 16/1: 26-30. KUNA ÁGNES - KOCSIS ZSUZSANNA - LUdÁNYI ZsÓFIA megj. a. A Magyar orvosi nyelv 16-17. századi alkorpusza. Tervezet, átírás, annotálás. In: FORGÁCS TAMÁS - NÉMETH MiKLÓs - SinKOVICS BALÁzS szerk., A nyelvtörténeti kutatások újabb eredményei IX. SZTE Magyar Nyelvészeti Tanszék, Szeged.

LANGACKER, RONALD W. 1987. Foundations of cognitive grammar 1. Theoretical prerequisites. Stanford University Press, Stanford.

LANGACKER, RONALD W. 2008. Cognitive Grammar. A basic introduction. Oxford University Press, New York.http://dx.doi.org/10.1093/acprof:oso/9780195331967.001.0001

NOTHDURFT, WERNER 1986. Das Muster im Kopf? Zur Rolle von Wissen und Denken bei der Konstitution interaktiver Muster. In: KALLMEYER, WERNER ed., Kommunikationstypologie. Handlungsmuster, Textsorten, Situationstypen. Schwann, Düsseldorf. 92-116.

PANTHER, KlaUs-UWE - THORNBURG, Linda L. 1997. Speech act metonymies. In: LiEBerT, WOLF-ANDREAS - REDEKER, GISELA - WAUGH, LINDA eds., Discourse and perspective in cognitive linguistics. Current Issues in Lingusitic Theory 151. John Benjamins, Amsterdam-Philadelphia. 205-219. http://dx.doi.org/10.1075/cilt.151.14tho

PANTHER, Klaus-UwE - THORnBURG, LindA L. 1998. A cognitive approach to inferencing in conversation. Journal of Pragmatics 30: 755-769. http://dx.doi.org/10.1016/[-] S0378-2166(98)00028-9

SHANK, ROGER - ABELSON, ROBERT 1977. Scripts, plans, goals, and understanding. Erlbaum, Hillsdale - New York.

SiMON GÁBOR 2016. Látlelet a müfajelméletröl - kutatási vázlat. Kézirat.

SINHA, CHRIS 2004. The epigenesis of symbolization. In: BALKENIUS, CHRISTIAN Zlatev, Jordan - Kozima, Hideki - Dautenhahn, Kerstin - BreaZeal, CynTHIA eds., Proceedings of the First International Workshop on Epigenetic Robotics: Modeling cognitive development in robotic systems. Lund University Cognitive Studies 85. Lund University Cognitive Science, Lund. 85-95.

STANNARD, JERRY 1982. Rezeptliteratur als Fachliteratur. In: EAMON, WiLliAm ed., Studies on Medieval Fachliteratur. Scripta 6. Omirel, Brussels. 59-73.

STUKKER, NinKE - SP OOREN, WILBERT - STEEN, GERARD eds., 2016. Genre in Language, Discourse and Cognition. De Gruyter, Berlin - New York. http://dx.doi.org/10.[-] 1515/9783110469639

SWALES, JOHN M. 1990. Genre analysis: English in academic and research settings. Cambridge University Press, Cambridge.

SZARVASHÁZI JUDIT 1999. A magyar gyógyszerészet képes reklámtörténete 1945-ig. Galenus Kiadó, Budapest.

SZLATKY MÁRIA 1980. Magyar nyelvü, kéziratos orvosló könyvek a 17. századból. Magyar Könyvszemle 96:131-148. 
TAAVITSAINEN, IRMA 2001a. Changing conventions of writing: the dynamics of genres, text types, and text traditions. European Journal of English Studies 5: 139-150.

TAAVITSAINEN, IRMA 2001b. Middle English recipes: Genre characteristics, text type features and underlying traditions of writing. Journal of Historical Pragmatics 2: 85113. http://dx.doi.org/10.1075/jhp.2.1.05taa

TAAVITSAINEN, IRMA - PAHTA, PÄIVI 2004. Vernacularisation of scientific and medical writing in its sociohistorical context. In: TAAVITSAINEN, IRMA - PAHTA, PÄIVI eds., Medical and scientific writing in late medieval English. Cambridge University Press, Cambridge. 1-19. http://dx.doi.org/10.1017/CBO9780511921193.002

TAAVITSAINEN, IRMA - JUCKER, ANDREAS H. 2010. Trends and developments in historical pragmatics. In: JUCKER, H. ANDREAS - TAAVITASINEN, IRMA eds., Historical pragmatics. Handbooks of Pragmatics 8. De Gruyter Mouton, Berlin - New York. 3-30. http://dx.doi.org/10.1515/9783110214284.1.3

TESz. = A magyar nyelv történeti-etimológiai szótára 1-3. Főszerk. BENKÖ LORÁND. Akadémiai Kiadó, Budapest, 1967-1976.

TolCSVAI NAGY GÁBOR 2006. A szövegtipológia megalapozása kognitív nyelvészeti keretben. In: TolCSVAI NAGY GÁBOR szerk., Szöveg és típus. Szövegtipológiai tanulmányok. Tinta Könyvkiadó, Budapest. 64-90.

Tomasello, Michael 2002. Gondolkodás és kultúra. Osiris Kiadó, Budapest.

ÚMTsz. = Új magyar tájszótár 1-5. Főszerk. B. LŐRINCZY ÉVA. Akadémiai Kiadó, Budapest, 1979-2010.

R. VÁRKONYI ÁGNES 1990. Közgyógyítás és boszorkányhit. Ethnographia 101: 384-437.

VersChUEREN, JeF 1999. Understanding pragmatics. Arnold, London - New York - Sydney - Auckland.

WERLICH, EGON 1976. A text grammar of Englsih. Quelle and Meyer, Heidelberg.

\section{Medical recipe as a genre in 16th-17th-century Hungarian}

\section{Genre in a functional cognitive framework}

Texts are always representatives of a given genre since they are embedded and function in a particular communicative situation. This paper analyses early Hungarian medical recipes as a genre from a functional cognitive perspective. According to this approach, genres are linguistic manifestations of socially and culturally determined cognitive patterns, linked to particular contexts, and conventionalized as prototypical representations for satisfying specific communicative needs. The goals of the paper are twofold. First, it discusses a range of theoretical assumptions informing the functional cognitive linguistic analysis of genres, also drawing on pragmatically oriented treatments of the topic. Second, the paper demonstrates the viability of viewing genres as complex schemas (scripts) through a detailed analysis of 16th and 17th-century Hungarian medical recipes. The research places special emphasis on the functional units of recipes (initiator, instructive and persuasive parts), and examines their role in the interpretation processes and genre activation of present-day Hungarian speakers. suasion.

Keywords: medical recipe, genre, scenario, cognitive linguistics, initiator, instruction, per-

KunA ÁGNES

MTA Támogatott Kutatócsoportok Irodája Pázmány Péter Katolikus Egyetem Károli Gáspár Református Egyetem 